\title{
The paediatric traveller
}

\section{Krzysztof Korzeniewski}

Department of Epidemiology and Tropical Medicine, Military Institute of Medicine, Warsaw, Poland

\begin{abstract}
International travel with children, which is the opportunity for the family to see the world together, has become commonplace. If you are travelling with children the journey needs to be carefully planned, especially in cases of visiting a region with harsh environment or poor sanitation. It is particularly important in terms of thermoregulation (hot climate) and the immune system (protection against pathogens causing infectious and invasive diseases) as these are not fully developed in small children. In addition, it is important to maintain appropriate safety and security measures in the destination area (e.g. using child car seats during drive, supervising children during recreational activities in water and on land, avoiding contact with undomesticated animals). Moreover, it is essential to prepare a travel health kit containing drugs appropriate for young travellers - matched for their age and body weight, and to purchase personal prevention products for everyday use (sunscreen with a high sun protection factor, insect repellents, etc.).
\end{abstract}

(Int Marit Health 2018; 69, 1: 70-74)

\section{Key words: child, international travel, tropics}

\section{INTRODUCTION}

As regards children, travel medicine currently focuses on four major areas: travel comfort and safety, vaccinations, prevention of vector-borne diseases and prevention and treatment of diarrheal illnesses [1]. The types of prevention measures to be taken before and throughout travel depend on a variety of factors, such as age, the general condition of a child (pre-travel health assessment is necessary, a child must be examined for allergies, dental caries, chronic infectious and non-infectious diseases), destination and time of travel. The benefits of travelling with children are quite obvious (spending time together, fun and play, learning values); however, travellers must be aware of certain health risks which may emerge, especially during overseas travel. The decision whether to take a child on a journey is up to their parents or guardians. Parents, however, need to be rational and use their common sense whenever they plan their travel activities. It is their decision whether to take their child on a trip to the jungle, a desert or in high mountains, or, if it is better to spend their holiday by a hotel swimming pool or on the beach. In general, travelling with children is becoming increasingly popular. Nowadays, children account for one in ten international travellers. Adult travellers take their children practically everywhere, unfortunately they tend to forget that in the wilderness of Africa, Asia or South America, where the nearest health care provider is tens or hundreds kilometres away, a travel health kit is not enough to save their child's life in an emergency. Inadequate risk assessment, i.e. evaluating the risk from the perspective of an adult, and disregard for the special requirements of paediatric travellers, whose thermoregulatory and immune systems are not yet fully developed (an increased risk of heat injuries and infections), is not only a lack of knowledge but also extreme irresponsibility [2-4].

\section{TRAVELLING BY PLANE}

Generally, air travel is considered safe for small children and infants. The barometric pressure as well as the oxygen concentration inside passenger aircrafts are reduced - the former corresponding to the altitude of 1800-2400 m above sea level, and the latter being the equivalent of $15 \%$ oxygen at sea level. Reduced oxygen content on a passenger plane is not problematic for healthy travellers, but it can pose a health hazard for children with chronic respiratory tract infections. Those children may require the administration of supplemental oxygen when travelling by air [5]. 


\section{TRAVELLING BY CAR}

Children should always travel in a car seat with their seatbelts fastened. Travellers to developing countries need to keep in mind that traffic laws are rarely obeyed by the locals. Therefore, it is extremely important for a driver to adjust their speed to the road conditions in a given destination and the nonchalance of local drivers; it will help ensure the safety for themselves and their passengers. In general, more international travellers die in traffic accidents than from infectious or invasive diseases, the statistics also apply to children. All travellers should be particularly careful when crossing the road because in some countries that fact that a pedestrian is on a zebra crossing does not necessarily mean they have priority. All over the world, there are countries where the car takes priority over the pedestrian and where drivers would use the horn or wave their hands to express their intentions; all travellers should remember about this, especially when travelling with children $[6,7]$.

\section{MOTION SICKNESS}

Motion sickness is a common condition associated with car, air or sea travel which is caused by intense motion. It occurs when there is a mismatch of information between the auditory and the visual system. While the visual system registers movement and sends appropriate signal to the brain, the vestibular system, which is responsible for the sense of balance, does not register motion. This leads to a mismatch of information between the two systems resulting in motion sickness with symptoms including nausea, vomiting, dizziness, sweating, excessive salivation. Motion sickness most often affects girls aged 2-12. Symptoms usually disappear as soon as motion (travel) stops. To prevent motion sickness, a child should be seated in a place where they will experience the least movement, e.g. the front seat in a car; the middle of a boat or a plane, best by a window, near the wing and on the right side of a plane. Before travel, children should not have heavy meals, sweets or fizzy drinks. In Poland, the most popular over-the-counter medication to prevent motion sickness is dimenhydrinate (Aviomarin syrup $12.5 \mathrm{mg} / 5 \mathrm{~mL}$; tab. $50 \mathrm{mg}$ ) which should be taken $30 \mathrm{~min}$ before travel at a dose of $1.25 \mathrm{mg} / \mathrm{kg}$ body mass, max. $50 \mathrm{mg}$ in a single dose (the onset of action after application is 20-30 min and the duration of action is usually 4-6 h). The drug is contraindicated in children under 2 years of age and those with epilepsy. Another popular drug to prevent motion sickness in children is promethazine (Diphergan syrup $5 \mathrm{mg} / 5 \mathrm{~mL}$ ). It can be used in children over the age of one year $[6,8]$.

\section{SKIN PROTECTION}

When travelling to destinations with intense sunlight, it is very important to take special precautions against sun- burns (sunscreen) and a sun stroke (hats). This particularly applies to children as their skin is much more sensitive and therefore more susceptible to sunburns. Firstly, you need to find out what skin type you child has. People with fair complexion (skin type I) are much more susceptible to sunburns than those with dark skin (skin type IV). When choosing a sunscreen, you should pay attention to the sun protection factor (SPF), which is defined as the UV energy required to produce a minimal erythema dose (MED) on protected skin, divided by the UV energy required to produce a MED on unprotected skin, or a measure of how quickly your skin will become sunburnt with or without protection. SPF 15 blocks approximately 93\%, and the SPF 30 blocks $96 \%$ of harmful UV radiation. In children, it is recommended to use a sunscreen with an SPF of at least 30, 15-30 min before sun exposure. Sunscreen needs to be reapplied each time after you take a bath, go swimming or if you sweat heavily. Sunscreen should not be used in children under 6 months; instead infants need to be kept in the shade away from direct sunlight $[6,9]$.

\section{VACCINATIONS}

In case of children, the vaccines administered before travel are usually a complement to national immunisation programmes $[10,11]$. In Poland, the compulsory immunisation schedule for children includes vaccinations against the following diseases: tuberculosis, diphtheria, tetanus, pertussis, polio, hepatitis $B$, measles, mumps, rubella and Haemophilus influenzae type $b$ invasive infection. Table 1 presents all mandatory (against yellow fever; invasive meningococcal disease for travellers to Saudi Arabia) and recommended vaccinations to be taken before travel [6]. Particular attention needs to be given to children with special health problems (children with allergies, diabetes, immunodeficiency disorders or those taking immunosuppressants) before they get vaccinated. In such cases, immunoprophylaxis needs to be individualized to avoid possible adverse events [12].

\section{PREVENTION OF VECTOR-BORNE DISEASES}

Before going abroad, especially to destinations where vector-borne diseases are endemic, travellers are recommended to buy all the necessary items for personal protection, first and foremost, insect repellents. When travelling to destinations where there are a lot of flying insects (e.g. mosquitoes, flies) always check if the air-conditioning in your hotel room is working properly (if it is available). Also, make sure if insect screens are tightly fitting the windows and ventilation grills and if a mosquito net around you bed is not damaged (spray it with Permethrin for additional protection). Travellers must also keep in mind that they can get bitten by other insects as well, e.g. ticks that are prevalent 
Table 1. Recommendations for the use of vaccinations in children. Source: [6]

\begin{tabular}{|c|c|c|}
\hline Disease & Dosage & Boosters \\
\hline Cholera & $\begin{array}{l}\text { Children aged 2- } 6 \text { years: } 3 \text { doses at the intervals of } 1-6 \text { weeks; } \\
\text { children over } 6 \text { years of age: } 2 \text { doses at the intervals of } 1-6 \text { weeks }\end{array}$ & $\begin{array}{l}\text { Immunity persists for } 6 \text { months (chil- } \\
\text { dren aged } 2-6 \text { years) and for up to } \\
2 \text { years (children over } 6 \text { years) }\end{array}$ \\
\hline Hepatitis A & $\begin{array}{l}2 \text { doses: } 0,6-12 \text { month (Havrix) the first dose given to children over } 2 \text { years } \\
\text { of age; } 0,6-36 \text { months (Avaxim) the first dose given to children at } 1 \text { year of } \\
\text { age; accelerated vaccination course against hepatitis A and B: day } 0,7,21 \\
\text { and a single booster dose after } 12 \text { months }\end{array}$ & $\begin{array}{l}\text { Not required according to WHO } \\
\text { recommendations }\end{array}$ \\
\hline $\begin{array}{l}\text { Typhoid fever (poly- } \\
\text { saccharide vaccine) }\end{array}$ & A single dose for children over the age of 2 years & Every $2-3$ years \\
\hline $\begin{array}{l}\text { Invasive meningo- } \\
\text { coccal disease }\end{array}$ & $\begin{array}{l}\text { A single dose for children over } 2 \text { months (Nimenrix); } \\
\text { for children over } 2 \text { years (Menveo) }\end{array}$ & $\begin{array}{l}\text { Not required according to the } \\
\text { manufacturer }\end{array}$ \\
\hline Rabies & $\begin{array}{l}\text { Pre-exposure vaccination - days: } 0,7,28 \text { (WHO recommendations: } \\
\text { days } 0,7,21 \text { or } 28 \text { ); a complementary dose: after } 12 \text { months } \\
\text { Post-exposure vaccination for previously immunised children: } 2 \text { doses } \\
\text { - on the day of being bitten and } 3 \text { days after; no age limitations }\end{array}$ & Every 5 years \\
\hline Yellow fever & A single dose for children over 9 months & $\begin{array}{l}\text { Not required according to WHO } \\
\text { recommendations }\end{array}$ \\
\hline $\begin{array}{l}\text { Tick-borne } \\
\text { encephalitis }\end{array}$ & $\begin{array}{l}3 \text { doses: } 0,1-3 \text { month, } 9-12 \text { month; the first dose for children } \\
\text { over the age of } 1 \text { year }\end{array}$ & Every 3 years \\
\hline
\end{tabular}

WHO - World Health Organisation

in deciduous forests, bushes, pastures with tall grass, or fleas and lice in areas with poor sanitation. To prevent insect bites travellers are recommended to cover as much of their body as possible (wearing long-sleeved shirts or tops, long trousers). Although many flying insects are most active from dusk to dawn, there are insects which stay active during the day e.g. tsetse flies transmitting African trypanosomiasis. To make matters worse, tsetse flies are insensitive to most repellents. Stagnant water is the favourite breeding ground for a number of flying insects. Therefore travellers are recommended to avoid staying outdoors and close to standing water after dark, when infection vectors (including mosquitoes transmitting malaria) are the most active.

The most common and readily available repellents are those containing N,N-diethyl-meta-toluamide (DEET). The research has showed that they are safe for children provided that they are only applied onto skin and no more than several times a day. Applying the repellent around the eyes can cause conjunctivitis, while inhaling or swallowing products containing DEET may produce symptoms indicating poisoning. Neurological disorders were reported in children using insect repellents more than 10 times during a day, especially if they were in a habit of licking the skin covered with the repellent. In general, products with a higher concentration of DEET will normally have a longer lasting effect, e.g. DEET concentration of 5-7\% provides protection for $1-2 \mathrm{~h}$ after application, whereas a concentration of $24 \%$ will ensure a 5 -h protection. The maximum concentration of DEET in products used on children should not exceed $30 \%$. Still, even if you regularly use insect repellents, a child may get bitten by a mosquito or other insects. If the bite is itchy or inflamed you should give your child an antihistamine e.g. topically applied dimethindene (Fenistil) gel or orally administered loratadine (Claritine) or cetirizine (Zyrtec) syrup or tablets. This will not only quickly relieve symptoms but also prevent a secondary bacterial infection, which is likely to occur as children tend to scratch itchy spots, which might lead to the formation of oozing lesions and secondary impetiginisation [6, 12-14].

\section{ANTIMALARIAL CHEMOPROPHYLAXIS}

Chloroquine, proguanil and mefloquine are recommended to breastfeeding mothers. Drug dosage regimen is based on a child's body weight. The bitter taste of antimalarials can be masked with sweet-tasting food or drinks. Chloroquine and proguanil are safe for young children; however, their use is limited owing to the growing resistance of Plasmodium to these drugs. Mefloquine can be used in children with the body weight of more than $5 \mathrm{~kg}$. Atovaquone/proguanil is recommended for children with the body weight of more than $11 \mathrm{~kg}$ (in the USA, Canada, Belgium and France - for children weighing more than $5 \mathrm{~kg}$ ). Doxycycline is contraindicated in children under the age of 8 years (Table 2$)[6,15,16]$.

\section{TREATMENT OF MALARIA}

$P$. vivax, $P$. ovale, $P$. malariae infections are usually treated with chloroquine, unless chloroquine-resistance has been confirmed. Severe malaria cases should be treated 
Table 2. Drugs used for antimalarial chemoprophylaxis in children. Source: [6]

\begin{tabular}{|c|c|c|c|}
\hline Drug & Dosage & $\begin{array}{l}\text { Duration } \\
\text { of chemoprophylaxis }\end{array}$ & Note \\
\hline $\begin{array}{l}\text { atovaquone/proguanil } \\
\text { paediatric tablet } \\
62.5 \mathrm{mg} / 25 \mathrm{mg}\end{array}$ & $\begin{array}{l}1 \times \text { day } \\
5-11 \mathrm{~kg} \text { bw: } 31.25 \mathrm{mg} / 12.5 \mathrm{mg} \\
11-20 \mathrm{~kg} \text { bw: } 62.5 \mathrm{mg} / 25 \mathrm{mg} \\
21-30 \mathrm{~kg} \text { bw: } 125 \mathrm{mg} / 50 \mathrm{mg} \\
31-40 \mathrm{~kg} \text { bw: } 187.5 \mathrm{mg} / 75 \mathrm{mg} \\
>40 \mathrm{~kg} \text { bw: } 250 \mathrm{mg} / 100 \mathrm{mg} \\
\text { (adult tablet) } 1 \times 1 \text { tablet }\end{array}$ & $\begin{array}{l}1 \text { day before travel, } \\
\text { every day during travel, } \\
7 \text { days after travel }\end{array}$ & $\begin{array}{l}\text { Very rare gastrointestinal, } \\
\text { dermatological adverse events }\end{array}$ \\
\hline $\begin{array}{l}\text { doxycycline } \\
\text { tablet } 100 \mathrm{mg}\end{array}$ & $\begin{array}{l}1 \times \text { day in children over } 8 \text { years of age } \\
2 \mathrm{mg} / \mathrm{kg} \text { bw (max } 100 \mathrm{mg} \text { per day) }\end{array}$ & $\begin{array}{l}1 \text { day before travel, } \\
\text { every day during travel, } \\
28 \text { days after travel }\end{array}$ & $\begin{array}{l}\text { Gastrointestinal, dermatological, } \\
\text { gynaecological adverse events }\end{array}$ \\
\hline $\begin{array}{l}\text { mefloquine } \\
\text { tablet } 250 \mathrm{mg}\end{array}$ & $\begin{array}{l}1 \times \text { week } \\
\text { < } 10 \mathrm{~kg}: 5 \mathrm{mg} / \mathrm{kg} \text { bw } \\
10-19 \mathrm{~kg}: 1 / 4 \text { tablet } \\
20-30 \mathrm{~kg}: 1 / 2 \text { tablet } \\
31-45 \mathrm{~kg}: 3 / 4 \text { tablet } \\
>45 \mathrm{~kg}: 1 \text { tablet }\end{array}$ & $\begin{array}{l}1 \text { week before travel, } \\
1 \times \text { week during travel, } \\
4 \text { weeks after travel }\end{array}$ & $\begin{array}{l}\text { Gastrointestinal, neuropsychiatric } \\
\text { adverse events }\end{array}$ \\
\hline $\begin{array}{l}\text { chloroquine } \\
\text { tablet } 150 \mathrm{mg}\end{array}$ & $\begin{array}{l}1 \times \text { week } \\
5 \mathrm{mg} / \mathrm{kg} \text { body weight (max } 300 \mathrm{mg})\end{array}$ & $\begin{array}{l}1 \text { week before travel, } \\
1 \times \text { week during travel, } \\
4 \text { weeks after travel }\end{array}$ & $\begin{array}{l}\text { Gastrointestinal, dermatological } \\
\text { adverse events; contraindicated } \\
\text { in epilepsy and psoriasis }\end{array}$ \\
\hline
\end{tabular}

with artesunate (intravenous or intramuscular administration) or with artemether or quinine if artesunate is unavailable. Parenteral therapy should be continued for at least $24 \mathrm{~h}$ and next be followed by the oral artemisinin-based combination therapy, artesunate + clindamycin or quinine + clindamycin (Table 3). Standby emergency treatment of malaria: artemether/lumefantrine (children with the body weight of more than $5 \mathrm{~kg}$, limited clinical data), atovaquone/ /proguanil (children with the body weight of more than $5 \mathrm{~kg}$, limited clinical data), dihydroartemisinin/piperaquine (children with the body weight of more than $10 \mathrm{~kg}$, limited clinical data) [6].

\section{PREVENTION OF FOOD- AND WATER-BORNE INFECTIONS}

Generally, the same principles of prevention apply to adults and children. However, there are several differences which need to be pointed out. If a child is breastfed, then it is crucial that the nursing mother has a healthy diet. If she avoids risk factors, her baby will be safe. This is extremely important, considering the fact that diarrheal diseases are more often seen in infants and toddlers (40\%) than older children (9-22\%). The highest prevalence of traveller's diarrhoea is reported among children under the age of 2 years. In order to avoid the transmission of food and waterborne infections it is extremely important that children frequently wash their hands (always before eating), because they often tend to put their fingers in their mouth or bite their nails. In
Table 3. Drugs used for the treatment of malaria in children. Source: [6]

\begin{tabular}{|c|c|}
\hline Drug & Dosage \\
\hline artesunate & $\begin{array}{l}2.4 \mathrm{mg} / \mathrm{kg} \text { bw IV or IM } \\
\left.0 \mathrm{~h}\left(1^{\text {st }} \text { dose }\right), 12 \mathrm{~h}\left(2^{\text {nd }} \text { dose }\right), 24 \mathrm{~h} \text { ( } 3^{\text {rd }} \text { dose }\right) \text {, } \\
\text { next: once daily }\end{array}$ \\
\hline artemether & $\begin{array}{l}\left.3.2 \mathrm{mg} / \mathrm{kg} \text { bw IM ( } 1^{\text {st }} \text { dose }\right) \\
\text { next: } 1.6 \mathrm{mg} / \mathrm{kg} \text { bw once daily }\end{array}$ \\
\hline quinine & $\begin{array}{l}20 \mathrm{mg} / \mathrm{kg} \text { bw IV infusion or IM } \\
\text { in } 3 \text { split doses administered every } 8 \mathrm{~h} \text { (initial dose) } \\
\text { next: } 10 \mathrm{mg} / \mathrm{kg} \text { bw IM } \\
\text { in } 3 \text { split doses administered every } 8 \mathrm{~h} \\
\text { Note: in case of IV administration the dose } \\
\text { cannot exceed } 5 \mathrm{mg} / \mathrm{kg} \text { bw per hour }\end{array}$ \\
\hline $\begin{array}{l}\text { artesunate } \\
+ \text { clindamycin }\end{array}$ & $\begin{array}{l}2 \mathrm{mg} / \mathrm{kg} \text { bw artesunate once daily for } \\
7 \text { days }+10 \mathrm{mg} / \mathrm{kg} \text { bw clindamycin twice } \\
\text { daily for } 7 \text { days }\end{array}$ \\
\hline chloroquine & $\begin{array}{l}25 \mathrm{mg} / \mathrm{kg} \text { bw in } 3 \text { split doses per day } \\
(10 \mathrm{mg} / \mathrm{kg}, 10 \mathrm{mg} / \mathrm{kg} \text { and } 5 \mathrm{mg} / \mathrm{kg}) \\
\text { for } 3 \text { consecutive days (do not use in } \\
P . \text { falciparum malaria) }\end{array}$ \\
\hline
\end{tabular}

countries with poor sanitation where tap water is likely to be contaminated, children should only be given bottled water, or alternatively physically or chemically purified water, for drinking, rinsing their mouth or brushing their teeth. Symptoms of the traveller's diarrhoea usually subside after a child has received an oral, or in more severe cases, intravenous rehydration therapy. In countries with a high prevalence 
of infectious diseases, the use of chemotherapeutics is recommended as they significantly reduce the severity and the duration of symptoms. In children, the first-line therapy of the traveller's diarrhoea is rehydration with intravenous fluids or oral rehydration salts and antimicrobials, such as azithromycin or ciprofloxacin. Azithromycin $(100 \mathrm{mg} / 5 \mathrm{~mL}$ or $200 \mathrm{mg} / 5 \mathrm{~mL}$ oral suspension; $250 \mathrm{mg}$ or $500 \mathrm{mg}$ tablets) is administered at a dose of $10 \mathrm{mg} / \mathrm{kg}$ bw once daily for $1-3$ days. Ciprofloxacin ( $250 \mathrm{mg} / 5 \mathrm{~mL}$ or $500 \mathrm{mg} / 5 \mathrm{~mL}$ oral suspension; $250 \mathrm{mg}$ or $500 \mathrm{mg}$ tablets) is used in children under the age of 1 year at a dose of $10 \mathrm{mg} / \mathrm{kg}$ bw twice a day for 1-3 days. Antimotility drugs, e.g. loperamide, are not recommended in small children (contraindicated $<6$ years) as they may cause retention of toxic substances in the gastrointestinal system [17-19].

\section{REFERENCES}

1. Summer AP, Fischer PR. The Pediatric and Adolescent Traveler. In: Keystone JS, Freedman DO, Kozarsky PE, Connor BA, Nothdurft HD. ed. Travel Medicine. 3rd Edition. Elsevier Saunders 2013: 231-240.

2. Jaeger VK, Tschudi N, Rüegg R, et al. The elderly, the young and the pregnant traveler - A retrospective data analysis from a large Swiss Travel Center with a special focus on malaria prophylaxis and yellow fever vaccination. Travel Med Infect Dis. 2015; 13(6): 475-484, doi: 10.1016/j.tmaid.2015.10.001, indexed in Pubmed: 26526774.

3. Stauffer W, Christenson JC, Fischer PR. Preparing children for international travel. Travel Med Infect Dis. 2008; 6(3): 101-113, doi:10.1016/j.tmaid.2008.02.004, indexed in Pubmed: 18486064.

4. Summer AP, Fischer PR. Travel with infants and children. Clin Fam Pract. 2005; 7: 729-743.

5. Udomittipong K, Stick SM, Verheggen M, et al. Pre-flight testing of preterm infants with neonatal lung disease: a retrospective review. Thorax. 2006; 61(4): 343-347, doi: 10.1136/thx.2005.048769, indexed in Pubmed: 16449269.

6. Korzeniewski K. Medycyna podróży. Kompendium. PZWL, Warszawa 2016.

7. Durbin DR. Committee on Injury, Violence, and Poison Prevention. Child passenger safety. Pediatrics. 2011; 127(4): e1050-e1066, doi:10.1542/peds.2011-0215, indexed in Pubmed: 21422094.
8. Takahashi M, Ogata M, Miura M. The significance of motion sickness in the vestibular system. J Vestib Res. 1997; 7(2-3): 179-187, indexed in Pubmed:9178223.

9. Diffey BL. When should sunscreen be reapplied? J Am Acad Dermatol. 2001; 45(6): 882-885, doi: 10.1067/mjd.2001.117385, indexed in Pubmed:11712033.

10. Greenwood CS, Greenwood NP, Fischer PR. Immunization issues in pediatric travelers. Expert Rev Vaccines. 2008; 7(5): 651-661, doi:10.1586/14760584.7.5.651, indexed in Pubmed: 18564019.

11. Rongkavilit C. Immunization for pediatric international travelers. Pediatr Ann. 2011; 40(7): 346-350, doi: 10.3928/0090448120110615-06, indexed in Pubmed: 21736256.

12. Weiberg N, Weinberg MS, Maloney SA. International Travel with Infants \& Children. In: Brunette GW. ed. CDC Yellow Book 2018. Health Information for International Travel. Oxford University Press, New York 2017.

13. Qiu H, Jun HW, McCall JW. Pharmacokinetics, formulation, and safety of insect repellent N,N-diethyl-3-methylbenzamide (deet): a review. J Am Mosq Control Assoc. 1998; 14(1): 12-27, indexed in Pubmed: 9599319.

14. Fradin MS, Day JF. Comparative efficacy of insect repellents against mosquito bites. N Engl J Med. 2002; 347(1): 13-18, doi: 10.1056/ NEJMoa011699, indexed in Pubmed: 12097535.

15. Osimitz TG, Murphy JV, Fell LA, et al. Adverse events associated with the use of insect repellents containing N,N-diethyl-m-toluamide (DEET). Regul Toxicol Pharmacol. 2010; 56(1): 93-99, doi: 10.1016/j.yrtph.2009.09.004, indexed in Pubmed: 19751786.

16. Fischer PR, Bialek R. Prevention of malaria in children. Clin Infect Dis. 2002; 34(4): 493-498, doi: 10.1086/338257, indexed in Pubmed: 11797176.

17. Schlagenhauf $P$, Adamcova M, Regep L, et al. Use of mefloquine in children - a review of dosage, pharmacokinetics and tolerability data. Malar J. 2011; 10: 292, doi: 10.1186/1475-2875-10-292, indexed in Pubmed: 21981927.

18. Stauffer WM, Konop RJ, Kamat D. Traveling with infants and young children. Part III: travelers' diarrhea. J Travel Med. 2002; 9(3): 141-150, doi:10.2310/7060.2002.23197, indexed in Pubmed: 12088580.

19. Grady RW. Systemic quinolone antibiotics in children: a review of the use and safety. Expert Opin Drug Saf. 2005; 4(4): 623-630, doi:10.1517/14740338.4.4.623, indexed in Pubmed: 16011441 